\title{
Kontribusi Sektor Pariwisata Terhadap Pendapatan Asli Daerah Kabupaten Nganjuk Tahun 2014 - 2018
}

\author{
M. Rois Muchlisin; Nining Purnamaningsih; Dwi Juwarni \\ Fakultas Ekonomi - Universitas Kadiri \\ E-mail : niningpurnamaningsih@ unik-kediri.ac.id
}

\begin{abstract}
This study aims to analyze: 1) Contributions and Growth of Tourism Object Levies on Nganjuk Regency Original Revenue in 2014-2018. 2) Contributions and Growth of Hotel and Restaurant Taxes on Nganjuk Regency Original Revenue for 2014-2018. 3) Contributions and Growth of Tourist Retribution on Local Revenue of Nganjuk Regency in 2014-2018. 4) Contribution and Growth of Tourism Sector Levies to Nganjuk Regency Original Revenue in 2014-2018. The type of research used in this study is descriptive quantitative. The analytical method used is descriptive descriptive. The types and sources of data use a quantitative approach with secondary data in the form of a time series with the observation period 2014 - 2018. The results show that: 1) There is a positive contribution between the Retribution of Tourism Objects to the Regional Income of Nganjuk Regency in 2014 - 2018 of 0.0060\% growth of 0,0007\%. 2) There is a positive contribution between the Hotel and Restaurant Taxes for the Ngapuk Regency's Original Regional Accounts for the year 2014 - 2018 amounting to 0.55\% and growth of $0.16 \%$. 3) There is a positive contribution between Tourist Retribution for the Regional Original Accountants of Nganjuk Regency in 2014 - 2018 amounting to $0.49 \%$ and growth of $-0.042 \%$. 4) There is a positive contribution between the acceptance of the Tourism Sector to the Ngapuk District's Original Regional Accounts for 2014-2020 at $1.05 \%$ and growth at 0.13\%.
\end{abstract}

Key Words : Regional Original Income; Tourism Sector

\section{ABSTRAK}

Penelitian ini bertujuan untuk menganalisis: 1) Kontribusi dan Pertumbuhan Retribusi Obyek Wisata terhadap Pendapatan Asli Daerah Kabupaten Nganjuk tahun 2014-2018. 2) Kontribusi dan Pertumbuhan Pajak Hotel dan Restoran terhadap Pendapatan Asli Daerah Kabupaten Nganjuk tahun 2014-2018. 3) Kontribusi dan Pertumbuhan Retribusi Wisatawan terhadap Pendapatan Asli Daerah Kabupaten Nganjuk tahun 2014-2018. 4) Kontribusi dan Pertumbuhan Retribusi Sektor Pariwisata terhadap Pendapatan Asli Daerah Kabupaten Nganjuk tahun 2014-2018. Jenis penelitian yang digunakan dalam penelitian ini adalah deskriptif kuantitatif. Metode analisis yang digunakan satatistik deskriptif. Jenis dan sumber data menggunakan pendekatan kuantitatif dengan data sekunder berupa deret waktu dengan periode pengamatan 2014 - 2018. Hasil penelitian menunjukkan bahwa: 1) Ada Kontribusi positif antara Retribusi Obyek Wisata terhadap Pendapatan Asli Daerah Kabupaten Nganjuk tahun 2014 - 2018 sebesar 0,0060\% dan pertumbuhan sebesar 0,0007\%. 2) Ada Kontribusi positif antara Pajak Hotel dan Restoran terhadap Pendapata Asli Daerah Kabupaten Nganjuk tahun 2014 - 2018 sebesar 0,55\% dan pertumbuhan sebesar 0,16\%. 3) Ada 
Kontribusi positif antara Retribusi Wisatawan terhadap Pendapata Asli Daerah Kabupaten Nganjuk tahun 2014 - 2018 sebesar 0,49\% dan pertumbuhan sebesar 0,042\%. 4) Ada Kontribusi positif antara penerimaan Sektor Pariwisata terhadap Pendapata Asli Daerah Kabupaten Nganjuk tahun 2014 - 2018 sebesar 1,05\% dan pertumbuhan sebesar 0,13\%.

Kata Kunci: Pendapatan Asli Daerah, Sektor Pariwisata.

\section{PENDAHULUAN}

Pelaksanaan otonomi daerah untuk memperkuat perekonomian domestik dan mendorong pemulihan ekonomi sudah berlangsung sejak Januari tahun 2001 yang lalu. Apabila selama ini upaya pemulihan ekonomi seolah-olah menjadi tanggung jawab pemerintah pusat saja, keberadaan otonomi daerah menciptakan peluang bagi daerahdaerah untuk ikut mempelopori upaya pemulihan ekonomi.

Setiap pemerintah daerah berupaya keras untuk meningkatkan perekonomian daerah, termasuk meningkatkan perolehan pendapatan asli daerah (PAD). Salah satu upaya untuk meningkatkan pendapatan asli daerah yaitu dengan mengoptimalisasikan potensi dalam sektor pariwisata. "Keberhasilan pengembangan sektor pariwisata pada suatu daerah yang ditunjukkan oleh peningkatan kontribusi terhadap PDRB (Putra \& Heryanto, 2017) serta kontribusi pajak daerah terhadap pendapatan asli daerah akan berpengaruh terhadap kinerja keuangan daerah". (Widiastuti:2010).

Tabel 1 : Penerimaan PAD Kabupaten Nganjuk Tahun 2014-2018

\begin{tabular}{|c|c|c|}
\hline Tahun & Jumlah (Rupiah) & Pertumbuhan (\%) \\
\hline 2014 & 255.957 .914 .871 & - \\
2015 & 287.881 .149 .708 & $12,4 \%$ \\
2016 & 323.045 .177 .741 & $12,2 \%$ \\
2017 & 332.495 .541 .853 & $2,9 \%$ \\
2018 & 359.592 .674 .230 & $8,1 \%$ \\
\hline
\end{tabular}

Sumber: Bapedda Kabupaten Nganjuk (2019)

Pada tabel di atas dijelaskan bahwa penerimaan Pendapatan Asli Daerah Kabupaten Nganjuk dari tahun 2014 sampai 2018 mengalami peningkatan. Kenaikan penerimaan PAD pada tahun 2015 ke 2016 dari segi nominal merupakan yang tertinggi sebesar Rp 35.164.028.033 dibandingkan penerimaan pada tahun 2014 ke 2015 hanya sebesar 31.923.234.837. Akan tetapi dari segi pertumbuhan penerimaan dalam persentase pada tahun 2015 mencapai 12,4\% sedangkan pada tahun 2016 sebesar 12,2\% selisih 0,2\% setiap tahunnya penerimaan Pendapatan Asli Daerah selalu meningkat walaupun pada pertumbuhannya mengalami penurunan terus menerus dikarenakan penerimaan retribusi mengalami fluktuatif penerimaan. 
Yenni (2016), menyebutkan bahwa penyelenggaraan kepariwisataan diarahkan untuk peningkatan kesejahteraan dan kemakmuran rakyat dalam rangka mewujudkan masyarakat adil dan makmur melalui peningkatan devisa, perluasan dan pemerataan kesempatan usaha dan lapangan kerja, mendorong pembangunan daerah, memperkaya kebudayaan nasional dengan tetap melestarikan kepribadian bangsa dan terpeliharanya nilai-nilai agama. Dalam mewujudkan tujuan penyelenggaraan kepariwisataan perlu keterpaduan peranan Pemerintah, badan usaha dan masyarakat secara serasi, selaras dan seimbang agar dapat mewujudkan potensi pariwisata nasional yang memiliki kemampuan daya saing ditingkat regional maupun global.

Kabupaten Nganjuk merupakan daerah di Jawa Timur yang memiliki julukan sebagai kota angin karena daerah kabupaten Nganjuk berada diantara Gunung wilis di sebelah selatan dan pegunungan Kendeng di sebelah utara. Dalam mendorong pembangunan ekonomi, Pemerintah daerah mengembangkan potensi wilayah yang memiliki akan pemandangan alam yang masih asri berupa gunung, air terjun, bukit, dan juga industri wisata seperti taman rekreasi. Di Kabupaten Nganjuk banyak tempat wisata yang dapat dituju oleh para wisatawan antara lain wisata alam, wisata budaya, wisata religi, wisata kuliner. Ada 4 objek wisata yang dikelola oleh pemerintah daerah yaitu Air Terjun Sedudo, Air Merambat Roro Kuning, Taman Rekreasi Anjuk Ladang, dan Goa Margo Trisno.

Selain obyek wisata (Dewandaru \& Purnamaningsih, 2016) adanya sarana akomodasi seperti ketersediaan hotel dan restoran menjadi hal wajib di setiap daerah. Selain sebagai penunjang para wisatawan yang akan berwisata ke daerah tujuan wisata, penerimaan pajak hotel dan restoran juga menambah kontribusi akan penerimaan dari sektor pariwisata terhadap Pendapatan daerah.

Tabel 2 : Jumlah Wisatawa di Kabupaten Nganjuk Tahun 2014-2018

\begin{tabular}{|c|c|c|c|}
\hline Tahun & Mancanegara & Domestik & Jumlah \\
\hline 2014 & 13 & 261.686 & 261.699 \\
2015 & 5 & 275.190 & 275.195 \\
2016 & 10 & 293.376 & 293.386 \\
2017 & 5 & 288.107 & 288.112 \\
2018 & - & 330.921 & 330.921 \\
\hline
\end{tabular}

Sumber: Dinas Pariwisata, Pemuda, Olahraga Dan Kebudayaan Kabupaten Nganjuk (2019)

Pada tabel 2 diketahui bahwa ada peningkatan jumlah wisatawan pada setiap tahunnya, akan tetapi pada tahun 2015 di obyek wisata air terjun Sedudo terjadi bencana 
alam tanah longsor yang mengakibatkan meninggalnya wisatawan yang sedang mandi di bawah air terjun. Hal tersebut membuat trauma masyarakat yang ingin berwisata ke air terjun Sedudo sehingga membuat jumlah kunjungan ke air terjun Sedudo mengalami penurunan. Pada tahun 2017 pemerintah menutup obyek wisata Sedudo selama 3 bulan untuk merenovasi obyek wisata tersebut agar menambah nilai dan daya tarik masyarakat untuk berwisata lagi ke Sedudo. Pada tahun 2018 terlihat peningkatan wisatawan di Sedudo, itu dilihat dari total jumlah kujungan di air terjun Sedudo pada tahun 2017 sebanyak 60.732 orang dan pada tahun 2018 sebanyak 116.530 orang.

Pengelolaan obyek wisata baru akan memberikan tambahan penerimaan pendapatan daerah dan meningkatkan pertumbuhan ekonomi di darah obyek wisata tersebut. Masih banyak obyek wisata yang masih dikelola oleh masyarakat, jika pemerintah bisa bekerjasama maka dapat dipastikan potensi penerimaan pada sektor pariwisata akan meningkat. Adapun masalah eksternal utama yang menghambat perkembangan pariwisata di Kabupaten Nganjuk adalah daya tarik obyek wisata yang kurang bagi para wisatawan regional sehingga wisatawan yang datang ke obyek wisata mayoritas adalah wisatawan lokal, selain itu perlu diadakannya kerjasama dengan praktisi kepariwisataan untuk mencari solusi meningkatkan daya tarik wisatawan.

Adapun tujuan yang ingin dicapai dari pelaksanaan penelitian ini adalah sebagai berikut:

1. Untuk mengetahui seberapa besar kontribusi dan pertumbuhan jumlah penerimaan retribusi obyek wisata terhadap Pendapatan Asli Daerah di Kabupaten Nganjuk.

2. Untuk mengetahui seberapa besar kontribusi dan pertumbuhan pajak hotel dan restoran terhadap Pendapatan Asli Daerah di Kabupaten Nganjuk.

3. Untuk mengetahui seberapa besar kontribusi dan pertumbuhan jumlah penerimaan retribusi wisatawan terhadap Pendapatan Asli Daerah di Kabupaten Nganjuk.

4. Untuk mengetahui seberapa besar kontribusi dan pertumbuhan penerimaan sektor pariwisata terhadap Pendapatan Asli Daerah di Kabupaten Nganjuk.

\section{TINJAUAN PUSTAKA}

\section{Pendapatan Asli Daerah (PAD)}

Pendapatan asli daerah (PAD) sebagai salah satu sumber keuangan daerah, pada hakikat tersebut diperoleh melalui mekanisme pajak dan retribusi atau pungutan lain yang dibebankan kepada masyarakat. Pendapatan asli daerah inilah yang dapat 
membuat daerah memiliki keleluasaan yang lebih besar untuk memaksimalkan potensi perolehan pendapatan daerah. (Adisasmita, 2011:40)

Menurut Anggoro (2017:18), Pendapatan Asli Daerah merupakan pendapatan yang diperoleh pemerintah daerah atas pelaksanaan kegiatan pemerintah dan pelayanan kepada masyarakat, serta pemanfaatan sumber daya yang dimiliki pemerintah daerah. Pendapatan ini sering kali dijadikan indikator tingkat kemajuan suatu daerah. Daerah yang dianggap maju adalah daerah yang memiliki PAD yang tinggi. Hal ini dapat dimengerti karena dengan tingginya PAD yang diterima suatu daerah maka tingkat ketergantungan Pemerintah Daerah terhadap Pemerintah Pusat dalam hal pendanaan APBD akan semakin berkurang.

Berdasarkan Undang-Undang No. 33 tahun 2004 tentang pertimbangan keuangan antara pemerintah pusat dan daerah, pendapatan asli daerah didefinisikan sebagai pendapatan yang diperoleh daerah yang dipungut berdasarkan peraturan daerah sesuai dengan peraturan perundang-undangan. Pada bab V No 1 disebutkan bahwa pendapatan asli daerah bersumber dari: pajak daerah, retribusi daerah, hasil pengolahan kekayaan daerah yang dipisahkan, dan lain-lain pendapatan asli daerah yang sah. PadaPasal 6 UU No. 33 Tahun 2004 ayat 1 dan 2 menyatakan bahwa, PAD bersumber dari: (Anggoro:2017)

1. Pajak Daerah

Anggoro (2017), Pajak Daerah yaitu pajak-pajak yang ditentukan pemungutannya dalam Peraturan Daerah, dan para pembayar pajak (wajib pajak) tidak menerima imbalan secara langsung dari pemerintah daerah. Contoh dari pajak daerah adalah pajak kendaraan bermotor, pajak hiburan, pajak rumah makan/restoran, pajak iklan, dan sebagainya.

Adisasmita (2011) menyatakan, bahwa pajak daerah adalah suatu iuran wajib untuk menyerahkan sebagian kekayaan kepada daerah sesuai peraturan perundang undangan yang ditetapkan oleh pemerintah daerah dan tidak ada jasa balik langsung dari pemerintah. Tujuan pemungutan pajak daerah ialah untuk kesejahteraan umum.

Undang-undang Nomor 28 Tahun 2009 tentang Pajak Daerah dan Retribusi Daerah, memberikan definisi " Pajak daerah yang selanjutnya disebut pajak adalah kontribusi wajib pajak kepada Daerah yang terutang oleh orang pribadi atau badan yang bersifat memaksa berdasarkan Undang-undang dengan tidak mendapatkan 
imbalan secara langsung dan digunakan untuk keperluan Daerah bagi sebesarbesarnya kemakmuran rakyat'. ( Anggoro,2017)

2. Retribusi Daerah

Sesuai dengan ketentuan Undang-undang Nomor 28 Tahun 2009 tentang Pajak Daerah dan Pendapatan Asli Daerah, yang dimaksud Retribusi Daerah yang selanjutnya disebut retribusi adalah pungutan daerah sebagai pembayaran atas jasa atau pemberian ijin tertentu yang khusus disediakan dan atau diberikan oleh pemerintah daerah untuk kepentingan orang pribadi atau badan. (Anggoro, 2017:244)

Menurut Adisasmita (2011), menyebutkan bahwa retribusi adalah pungutan yang dilakukan berhubungan dengan jasa fasilitas yang diberikan oleh pemerintah secara langsung dan nyata kepada masyarakat. Ciri-ciri pokok retribusi daerah adalah:

a. Pemungutan dilakukan oleh pemerintah daerah

b. Pengenaan pungutan bersifat imbal prestasi atas jasa yang diberikan pemerintah daerah

c. Dikenakan kepada orang atau badan yang memanfaatkan jasa yang disediakan oleh pemerintah daerah

Ruang lingkup retribusi sektor pariwisata sebagai obyek penelitian ini meliputi retribusi tempat rekreasi dan retribusi olah raga yang dikelola oleh Dinas Pemuda, Olah Raga, Kebudayaan dan Pariwisata. Adapun obyek retribusi meliputi tanda masuk perorangan, tanda masuk kendaraan, penggunaan fasilitas tempat rekreasi, tempat parkir khusus di lingkungan tempat rekreasi.

\section{Pariwisata}

Pengertian kata pariwisata berasal dari bahasa sansekerta yaitu kata "pari" yang berarti banyak, berkali-kali, berputar-putar, kata "wisata" yang berarti perjalanan, bepergian. Pariwisata dalam bahasa inggris adalah "tour" yang diartikan dalam kamus sebagai perjalanan atau bepergian untuk kesenangan mengunjungi berbagai tempat yang menarik, atau kunjungan singkat atau kunjungan lewat suatu tempat.

Muljadi (2010) istilah pariwisata berasal dari dilaksanakan kegiatan wisata (tour), yaitu suatu aktivitas perubahan tempat tinggal sementara dari seseorang, di luar tempat tinggal sehari-hari dengan suatu alasan apapun selain melakukan kegiatan yang bisa menghasilkan upah atau gaji. 
Dengan demikian, dapat diambil kesimpulan bahwa pariwisata adalah suatu bidang industri yang dapat menarik seseorang untuk berkunjung ke suatu daerah wisata yang menjadi sasaran wisata karena adanya daya tarik wisata serta usaha-usaha yang terkait dengan bidang pariwisata tersebut, serta keseluruhan fenomena alam dan buatan manusia dimanfaatkan untuk kepentingan wisatawan, yaitu memenuhi kebutuhan wisatawan selama melakukan perjalanan wisata.

\section{Pajak Hotel}

Sesuai dengan Undang-Undang Nomor 28 Tahun 2009 Pasal 1 ayat 20 dan 21, pajak hotel adalah pajak atas pelayanan yang disediakan oleh hotel. Sedangkan yang dimaksud dengan hotel adalah fasilitas penyedia jasa penginapan/ peristirahatan termasuk jasa terkait lainnya dengan dipungut bayaran, yang mencakup juga motel, losmen, gubuk pariwisata, wisma pariwisata, pesanggrahan, rumah penginapan dan sejenisnya, serta rumah kos dengan jumlah kamar lebih dari sepuluh (Siahaan, 2009:299-300).

Tarif tertinggi Pajak Hotel sesuai yang diatur dalamUndang-undang Nomor 28 tahun 2009 pasal 35 ayat 1 adalah sebesar $10 \%$.

\section{Pajak Restoran}

Sesuai dengan Undang-Undang Nomor 28 Tahun 2009 Pasal 1 ayat 22 dan 23, pajak restoran adalah pajak atas pelayanan yang disediakan oleh restoran. Sedangkan yang dimaksud dengan restoran adalah fasilitas penyedia makanan dan atau minuman dengan dipungut bayaran, yang mencakup juga rumah makan, kafetaria, kantin, warung, bar dan sejenisnya termasuk jasa boga/catering (Siahaan, 2009:327-328).

Siahaan (2009:331-333) menyatakan bahwa dasar pengenaan pajak restoran adalah jumlah pembayaran yang diterima atau yang seharusnya diterima restoran. Tarif pajak restoran ditetapkan paling tinggi sebesar 10\% (sepuluh persen) dan ditetapkan dengan peraturan daerah kabupaten/kota yang bersangkutan.

\section{Hipotesis}

Hipotesis yang diajukan dalam penelitian ini adalah:

1. Kontribusi dan pertumbuhan penerimaan retribusi obyek wisata positif terhadap Pendapatan Asli Daerah di Kabupaten Nganjuk.

2. Kontribusi dan pertumbuhan Pajak hotel dan restoran positif terhadap Pendapatan Asli Daerah di Kabupaten Nganjuk.

3. Kontribusi dan pertumbuhan penerimaan retribusi wisatawan positif terhadap Pendapatan Asli Daerah di Kabupaten Nganjuk. 
4. Secara bersama-sama kontribusi dan pertumbuhan penerimaan retribusi obyek wisata, pajak hotel dan restoran, jumlah penerimaan retribusi wisatawan, positif terhadap Pendapatan Asli Daerah di Kabupaten Nganjuk.

\section{METODOLOGI PENELITIAN}

\section{Populasi Dan Sampel Penelitian}

Populasi yang akan digunakan dalam penelitian ini terdiri dari Jumlah penerimaan retribusi objek wisata, pajak hotel dan restoran, jumlah penerimaan retribusi wisatawan dalam bentuk data sekunder yang terdapat pada laporan Pendapatan Asli Daerah Kabupaten Nganjuk tahun 2014 - 2018.

Sedangkan sampel dalam penelitian ini adalah hasil laporan Pendapatan Asli Daerah tentang Jumlah penerimaan retribusi objek wisata, Pajak hotel dan restoran, Jumlah penerimaan retribusi wisatawan dari tahun 2014 - 2018 di Kabupaten Nganjuk.

Metode penentuan sampel dalam penelitian ini adalah metode sampel jenuh. Metode sampel jenuh adalah teknik penentuan sampel bila semua anggota populasi digunakan menjadi sampel (Sugiyono, 2011).

\section{Variabel Penelitian Dan Definisi Operasional}

Variabel yang digunakan dalam penelitian ini dapat diperinci sebagai berikut:

1. Variabel Dependen (Y)

Variabel dependen (Variabel Terikat) yaitu variabel yang dijelaskan atau dipengaruhi oleh variabel yang lain (Indriantoro, 2011). Variabel dependen dalam penelitian ini adalah Pendapatan Asli Daerah.

2. Variabel Independen (X)

Variabel indepenten (Variabel Bebas) yaitu variabel yang mempengaruhi variabel lainnya (Indriantoro, 2011).Variabel bebas dalam penelitian ini adalah:

a. Variabel $\left(\mathrm{X}_{1}\right)$ : Jumlah penerimaan retribusi Obyek Wisata

b. Variabel $\left(\mathrm{X}_{2}\right)$ : Pajak Hotel dan Restoran

c. Variabel $\left(\mathrm{X}_{3}\right)$ : Jumlah penerimaan retribusi Wisatawan

Sedangkan definisi operasional adalah suatu informasi mengenai cara mengukur variabel dan memberikan informasi untuk penulis lain yang ingin menggunakan variabel yang sama.

1. Pendapatan Asli Daerah (PAD) 
Data mengenai Pendapatan Asli Daerah (PAD) diperoleh dari Laporan Realisasi Anggaran Pendapatan Asli Daerah dari tahun 2014 - 2018, data tersebut diperoleh dari Badan Pendapatan Kabupaten Nganjuk yang dinyatakan dalam satuan rupiah.

2. Jumlah penerimaan retribusi Obyek Wisata

Penerimaan retribusi obyek wisata terdiri dari penerimaan sewa bedag, tempat parkir, kamar mandi dan fasilitas umum yang berada di tempat pariwisata. Data mengenai jumlah objek wisata diperoleh dari Dinas Pariwisata Kabupaten Nganjuk dari tahun 2014 - 2018 yang dinyatakan dalam satuan rupiah.

3. Pajak Hotel dan restoran

Tarif tertinggi Pajak Hotel dan restoran sesuai yang diatur dalam Undang-undang Nomor 28 tahun 2009 pasal 35 ayat 1 adalah sebesar 10\%. Data diperoleh dari laporan realisisasi anggaran pendapatan asli daerah Kabupaten Nganjuk tahun 2014 - 2018 yang dinyatakan dalam satuan rupiah.

4. Jumlah penerimaan retribusi wisatawan

Penerimaan retribusi wisatawan diperoleh dari retribusi karcis masuk di objek wisata, data mengenai jumlah penerimaan retribusi objek wisatawan diperoleh dari Dinas Pariwisata Kabupaten Nganjuk dari tahun 2014 - 2018 yang dinyatakan dalam satuan rupiah.

\section{Metode Pengumpulan Data}

Penelitian ini menggunakan metode dokumentasi yang berupa data sekunder, dengan periode pengamatan tahun 2014 - 2018. Data sekunder yang digunakan untuk penelitian ini diperoleh dari laporan suatu lembaga terkait. Data yang digunakan antara lain:

1. Jumlah Wisatawan Kabupaten Nganjuk yang diperoleh dari, Dinas Pariwisata dan Kebudayaan Kabupaten Nganjuk.

2. Jumlah Obyek Wisata Kabupaten Nganjuk yang diperoleh dari, Dinas Pariwisata dan Kebudayaan Kabupaten Nganjuk.

3. Pajak Hotel dan Restoran yang diperoleh dari Badan Pendapatan Daerah Kabupaten Nganjuk.

4. Pendapatan Asli Daerah yang diperoleh dari Badan Pendapatan Daerah Kabupaten Nganjuk.

\section{Metode Analisis Data}

Penelitian ini menggunakan statistik deskriptif, yaitu statistik yang digunakan untuk menganalisis data dengan cara mendeskripsikan atau menggambarkan data yang 
telah terkumpul sebagaimana adanya tanpa bermaksud membuat kesimpulan yang berlaku untuk umum atau generalisasi (Sanusi, 2011:115). Yang termasuk dalam statistik deskriptif adalah penyajian data dengan tabel, grafik, diagram lingkaran, piktogram, perhitungan modus, median, mean, presentase, dan strandar deviasi.

Dari data yang diperoleh baik berbentuk tabel, dokumen, dan lain-lain, kemudian data dianalisis, dideskripsikan, dan diambil kesimpulan. Untuk menganalisis data ini, digunakan teknik analisis data kualitatif. Ada tiga alur kegiatan dalam menganalisis data kualitatif, yaitu :

1. Reduksi Data (Reduction Data)

Reduksi data diartikan sebagai proses pemilihan, pemisahan, perhatian pada penyederhanaan, pengabstrakan dan transformasi data kasar yang muncul dari catatan-catatan tertulis di lapangan. Laporan atau data yang diperoleh di lapangan akan dituangkan dalam bentuk uraian yang lengkap dan terperinci. Data yang diperoleh dari lapangan jumlahnya akan cukup banyak, sehingga perlu dicatat secara teliti dan rinci. Mereduksi data berarti merangkum, memilih hal-hal pokok, memfokuskan pada hal-hal yang penting, serta dicari tema dan polanya.

Jika dalam penelitian kualitatif terdapat data yang bersifat kuantitatif, yaitu dalam bentuk angka-angka, maka sebaiknya angka-angka jangan dipisahkan dari kata-katanya secara konstektual sehingga tidak mengurangi maknanya.

2. Penyajian Data (Data Display)

Penyajian data dilakukan dengan tujuan untuk mempermudah peneliti dalam melihat gambaran secara keseluruhan atau bagian tertentu dari penelitian. Penyajian data dilakukan dengan cara mendeskripsikan hasil informasi yang dituangkan dalam bentuk uraian dengan teks naratif, dan didukung oleh dokumen-dokumen, serta foto-foto maupun gambar sejenisnya untuk diadakannya suatu kesimpulan.

3. Penarikan Kesimpulan(Concluting Drawing)

Penarikan kesimpulan atau verifikasi merupakan kegiatan akhir penelitian kualitatif. Peneliti harus sampai pada kesimpulan dan melakukan verifikasi, baik dari segi makna maupun kebenaran kesimpulan yang disepakati oleh tempat penelitian itu dilaksanakan. Makna yang dirumuskan peneliti dari data harus diuji kebenaran, kecocokan, dan kekokohannya. Peneliti harus menyadari bahwa dalam mencari makna, ia harus menggunakan pendekatan emik, yaitu dari kacamata key information, dan bukan penafsiran makna menurut pandangan peneliti (pandangan etik). 


\section{HASIL PENELITIAN DAN PEMBAHASAN}

\section{Penerimaan Pendapatan Asli Daerah Dari Retribusi Dan Pajak Sektor Pariwisata}

Perolehan dana dari retribusi dan pajak sektor pariwisata ini dikelompokkan menjadi tiga, yaitu besarnya sumbangan retribusi dan pajak sektor pariwisata terhadap pendapatan asli daerah,prosentase besarnya retribusi dan pajak sektor pariwisata terhadap pendapatan asli daerah, dan prosentase pertumbuhan retribusi dan pajak sektor pariwisata terhadap pendapatan asli daerah Kabupaten Nganjuk.

1. Besarnya sumbangan retribusi dan pajak pariwisata terhadap Pendapatan Asli Daerah

Yang dimaksud besarnya sumbangan retribusi dan pajak pariwisata terhadap Pendapatan Asli Daerah ini adalah sejumlah dana yang berasal dari retribusi dan pajak sektor pariwisata yang berhasil disetor ke kas daerah Kabupaten Nganjuk dan dicatat sebagai penerimaan pendapatan asli daerah.

2. Prosentase besarnya sumbangan retribusi dan pajak pariwisata terhadap Pendapatan Asli Daerah

Yang dimaksud Prosentase besarnya sumbangan retribusi dan pajak pariwisata terhadap Pendapatan Asli Daerah ini adalah perbandingan antara penerimaan retribusi dan pajak sektor pariwisata dengan total pendapatan asli daerah Kabupaten Nganjuk. Prosentase ini dimaksudkan untuk mengetahui besarnya kontribusi sumbangan sektor pariwisata terhadap pendapatan asli daerah.

3. Prosentase pertumbuhan retribusi dan pajak sektor pariwisata terhadap Pendapatan Asli Daerah

Yang dimaksud prosentase pertumbuhan retribusi dan pajak sektor pariwisata terhadap Pendapatan Asli Daerah ini adalah selisih per tahun dari prosentase sumbangan sektor pariwisata terhadap pendapatan asli daerah. Tujuan prosentase ini ialah untuk mengetahui apakah pertumbuhan sumbangan sektor pariwisata per tahun mengalami peningkatan atau penurunan dibandingkan pada tahun sebelumnya. 


\section{Hasil Penelitian}

Untuk mengetahui seberapa besar kontribusi yang dapat diberikan oleh sektor pariwisata terhadap pendapatan asli daerah, menggunakan perhitungan sebagai berikut: (Shintya, 2016)

$$
\text { Kontribusi }=\frac{\text { Pendapatan Sektor Pariwisata }}{\text { PAD }} \times 100 \%
$$

Sedangkan untuk mengetahui pertumbuhan kontribusi terhadap Pendapatan Asli Daerah yaitu dengan cara mencari berbandingan angka dari tahun sekarang dengan tahun sebelumnya, apakah mengalami kenaikan atau penurunan.

\section{Penerimaan Retribusi Objek Wisata Terhadap Pendapatan Asli Daerah Kabupaten Nganjuk}

Pendapatan Asli Daerah didapat dari hasil seluruh sektor ekonomi di daerah. Salah satu yang menjadi penyumbang Pendapatan Asli Daerah adalah sektor pariwisata khususnya retribusi objek wisata. Retribusi objek wisata didapat dari penerimaan sewa bedag dan penggunaan fasilitas umum di sekitar objek wisata.

Tabel 3 : Realisasi Penerimaan Retribusi Objek Wisata Terhadap PAD

\begin{tabular}{|c|c|c|c|c|}
\hline Tahun & $\begin{array}{c}\text { Retribusi objek } \\
\text { wisata } \\
(\mathrm{Rp})\end{array}$ & $\begin{array}{c}\text { PAD } \\
(\mathrm{Rp})\end{array}$ & $\begin{array}{c}\text { Persentase } \\
(\%)\end{array}$ & $\begin{array}{c}\text { Pertumbuhan } \\
(\%)\end{array}$ \\
\hline 2014 & 13.597 .785 & 255.957 .914 .871 & $0,0053 \%$ & - \\
\hline 2015 & 11.716 .768 & 287.881 .149 .708 & $0,0040 \%$ & $(0,0013 \%)$ \\
\hline 2016 & 16.103 .415 & 323.045 .177 .741 & $0,0049 \%$ & $0,0009 \%$ \\
\hline 2017 & 24.283 .255 & 332.495 .541 .853 & $0,0073 \%$ & $0,0024 \%$ \\
\hline 2018 & 29.318 .805 & 359.592 .674 .230 & $0,0081 \%$ & $0,0008 \%$ \\
\hline Rata-rata & $\mathbf{1 8 . 8 0 4 . 0 0 5}$ & $\mathbf{3 1 1 . 7 8 0 . 4 9 1 . 6 8 0}$ & $\mathbf{0 , 0 0 6 0 \%}$ & $\mathbf{0 , 0 0 0 7 \%}$ \\
\hline
\end{tabular}

Sumber : Data Sekunder Yang Diolah Peneliti (2019)

Tabel 3 menunjukkan bahwa rata-rata kontribusi retribusi objek wisata selama lima tahun sebesar $0,0060 \%$ terhadap PAD, dengan rincian pada tahun 2014 penerimaaa retribusi objek wisata sebesar Rp 13.597.785 dan memberikan kontribusi terhadap PAD sebesar $0,0053 \%$. Sedangkan pada tahun 2015 penerimaan retribusi objek wisata turun menjadi Rp 11.716.768 dan memberikan kontribusi kepada PAD sebesar 0,0040 \%, yang artinya pertumbuhannya turun 0,0013 \% dibanding tahun 2014. Pada tahun 2016 
penerimaan retribusi objek wisata naik sebesar $\mathrm{Rp} 16.103 .415$ dan memberikan kontribusi terhadap PAD sebesar 0,0049\%, meningkat 0,0009\% dari tahun 2015 .

Kemudian pada tahun 2017 penerimaan retribusi objek wisata mengalami kenaikan lagi sebesar Rp 24.283.255 dan memberikan kontribusi terhadap PAD sebesar 0,0073\%, meningkat 0,0024\% dibanding tahun 2016. Tahun 2018 penerimaan retribusi objek wisata naik menjadi Rp 29.318.805, memberikan kontribusi terhadap PAD sebesar $0,0081 \%$, meningkat $0,0008 \%$ dibandingkan tahun 2017. PAD pada tahun 2014 sampai tahun 2018 mengalami kecenderungan kenaikan terus.

Pada tahun 2017 pertumbuhan pendapatannya meningkat drastis sebesar 0,0024\% dikarenakan sewa bedag di TRAL naik, selain itu pemerintah berhasil mengakuisisis 30\% penerimaan parkir di objek wisata Goa Margo Tresno yang dulunya dikelola seluruhnya oleh masyarakat sekitar objek wisata tersebut.

\section{Penerimaan Pajak Hotel Dan Restoran Terhadap Pendapatan Asli Daerah} Kabupaten Nganjuk

Selain penerimaan dari retribusi, sektor pariwisata juga menyumbang pendapatan daerah melalui pajak hotel dan restoran yang menjadi penunjang akomodasi dalam pariwisata di Kabupaten Nganjuk dan memberikan kontribusi terhadap Pendapatan Asli Daerah sebagai berikut:

Tabel 4 : Realisasi Penerimaan Pajak Hotel Dan Restauran Terhadap PAD

\begin{tabular}{|c|c|c|c|c|}
\hline Tahun & $\begin{array}{c}\text { Pajak hotel dan } \\
\text { restauran } \\
(\mathrm{Rp})\end{array}$ & $\begin{array}{c}\text { PAD } \\
(\mathrm{Rp})\end{array}$ & $\begin{array}{c}\text { Persentase } \\
(\%)\end{array}$ & $\begin{array}{c}\text { Pertumbuhan } \\
(\%)\end{array}$ \\
\hline 2014 & 219.244 .450 & 255.957 .914 .871 & $0,085 \%$ & - \\
\hline 2015 & 1.663 .409 .904 & 287.881 .149 .708 & $0,57 \%$ & $0,49 \%$ \\
\hline 2016 & 1.913 .347 .698 & 323.045 .177 .741 & $0,59 \%$ & $0,02 \%$ \\
\hline 2017 & 2.331 .363 .295 & 332.495 .541 .853 & $0,70 \%$ & $0,11 \%$ \\
\hline 2018 & 2.594 .300 .334 & 359.592 .674 .230 & $0,72 \%$ & $0,02 \%$ \\
\hline Rata-rata & $\mathbf{1 . 7 4 4 . 3 3 3 . 1 3 6}$ & $\mathbf{3 1 1 . 7 8 0 . 4 9 1 . 6 8 0}$ & $\mathbf{0 , 5 5 \%}$ & $\mathbf{0 , 1 6 \%}$ \\
\hline
\end{tabular}

Sumber : Data Sekunder Yang Diolah Peneliti (2019)

Pada tabel 4 menjelaskan bahwa rata-rata kontribusi penerimaan pajak hotel dan restoran selama lima tahun sebesar $0,55 \%$ terhadap $\mathrm{PAD}$, dengan rincian pada tahun 2014 sebesar Rp 219.244.450, dan memberikan kontribusi terhadap PAD sebesar 0,085\%. Pada tahun 2015 penerimaan pajak hotel dan restoran meningkat menjadi Rp 1.663.409.904, dan memberikan kontribusi terhadap PAD sebesar 0,57\%, naik pesat 
0,49\% dibanding tahun 2014. Kemudian pada tahun 2016 penerimaan pajak pajak hotel dan restoran sebesar Rp 1.913.347.698, dan memberikan kontribusi terhadap PAD sebesar $0,57 \%$, meningkat $0,002 \%$ dibandingkan pada tahun 2015. Kemudian pada tahun 2017 penerimaan pajak hotel dan restoran menjadi Rp 2.331.363.295, dan memberikan kontribusi terhadap PAD sebesar $0,70 \%$, meningkat $0,11 \%$ dibandingkan pada tahun 2016. Pada tahun 2018 penerimaan pajak hotel dan restoran menjadi Rp 2.594.300.334, dan memberikan kontribusi terhadap PAD sebesar 0,72\%, meningkat 0,02\% dibandingkan pada tahun 2017.

Pada tahun 2015 penerimaan pada Pajak restoran meningkat drastis dari $\mathrm{Rp}$ 122.092.450 pada tahun 2014 menjadi Rp 1.559.249.268 pada tahun 2015, hal tersebut disebabkan karena pada tahun anggaran 2015 terjadi penambahan wajib pajak yaitu katering, yang pada tahun 2014 belum ditetapkan sebagai wajib pajak.

\section{Penerimaan Retribusi Wisatawan Terhadap Pendapatan Asli Daerah Kabupaten Nganjuk}

Penerimaan retribusi wisatawan diambil dari hasil penerimaan karcis masuk di obyek wisata yang memberikan tambahan pendapatan terhadap sektor pariwisata. Penerimaan retribusi ini didukung dengan jumlah pengunjung yang berwisata pada setiap tahun.

Tabel 5 : Realisasi Penerimaan Retribusi Karcis Masuk Wisatawan Terhadap

PAD

\begin{tabular}{|c|c|c|c|c|}
\hline Tahun & $\begin{array}{c}\text { Retribusi } \\
\text { Karcis Masuk } \\
(\mathrm{Rp})\end{array}$ & $\begin{array}{c}\text { PAD } \\
(\mathrm{Rp})\end{array}$ & $\begin{array}{c}\text { Persentase } \\
(\%)\end{array}$ & $\begin{array}{c}\text { Pertumbuhan } \\
(\%)\end{array}$ \\
\hline 2014 & 1.519 .170 .000 & 255.957 .914 .871 & $0,67 \%$ & - \\
\hline 2015 & 1.519 .185 .000 & 287.881 .149 .708 & $0,52 \%$ & $(0,15 \%)$ \\
\hline 2016 & 1.463 .280 .000 & 323.045 .177 .741 & $0,45 \%$ & $(0,07 \%)$ \\
\hline 2017 & 1.332 .438 .000 & 332.495 .541 .853 & $0,40 \%$ & $(0,05 \%)$ \\
\hline 2018 & 1.815 .745 .000 & 359.592 .674 .230 & $0,50 \%$ & $0,10 \%$ \\
\hline Rata-rata & $\mathbf{1 . 5 2 9 . 9 6 3 . 6 0 0}$ & $\mathbf{3 1 1 . 7 8 0 . 4 9 1 . 6 8 0}$ & $\mathbf{0 , 4 9 \%}$ & $\mathbf{( 0 , 0 4 2 \% )}$ \\
\hline
\end{tabular}

Sumber : Data Sekunder Yang Diolah Peneliti (2019)

Tabel 5 menjelaskan bahwa rata-rata kontribusi sektor pariwisata selama lima tahun sebesar 0,49\% terhadap PAD, dengan rincian pada tahun 2014 penerimaan karcis masuk wisatawan sebesar Rp 1.519.170.000, memberikan kontribusi terhadap PAD sebesar 0,67 \%. Pada tahun 2015 penerimaan retribusi karcis naik menjadi Rp 
1.519.185.000, dan memberikan kontribusi terhadap PAD sebesar 0,52 \% yang berarti turun $0,15 \%$ dari tahun 2014. Pada tahun 2016 penerimaan retribusi karcis turun menjadi 1.463.280.000, memberikan kontribusi terhadap PAD sebesar 0,45\%, turun 0,07\% dari tahun 2015. Kemudian pada tahun 2017 penerimaan retribusi karcis turun lagi menjadi Rp 1.332.745.000, memberikan kontribusi terhadap PAD sebesar 0,40\%, turun $0,05 \%$ dibanding tahun 2016. Pada tahun 2018 penerimaan retribusi karcis meningkat drastis menjadi Rp 1.815.745, dan memberikan kontribusi terhadap PAD sebesar 0,50\%, naik 0,10\% dibanding tahun 2017 .

Pada tabel di atas tahun 2017 penerimaan retribusi karcis masuk wisatawan merupakan yang terendah dan mengakibatkan menurunnya kontribusi terhadap PAD. Hal ini disebabkan karena pada tahun 2017 objek wisata Sedudo ditutup selama 3 bulan untuk umum lantaran adanya renovasi atau pembangunan sarana prasarana objek wisata.

Penerimaan Sektor Pariwisata Terhadap Pendapatan Asli Daerah

\section{Kabupaten Nganjuk}

Penerimaan sektor pariwisata ini dihasilkan dari jumlah keseluruhan dari penerimaan retribusi objek wisata, pajak hotel dan restoran, retribusi wisatawan dan kemudian dicari seberapa besar kontribusinya terhadap pendapatan asli daerah.

\section{Tabel 6 : Realisasi Penerimaan Pariwisata Terhadap PAD}

\begin{tabular}{|c|c|c|c|c|}
\hline Tahun & $\begin{array}{c}\text { Pariwisata } \\
(\mathrm{Rp})\end{array}$ & $\begin{array}{c}\text { PAD } \\
(\mathrm{Rp})\end{array}$ & $\begin{array}{c}\text { Persentase } \\
(\%)\end{array}$ & $\begin{array}{c}\text { Pertumbuhan } \\
(\%)\end{array}$ \\
\hline 2014 & 1.752 .012 .235 & 255.957 .914 .871 & $0,68 \%$ & - \\
\hline 2015 & 3.194 .311 .672 & 287.881 .149 .708 & $1,10 \%$ & $0,42 \%$ \\
\hline 2016 & 3.382 .731 .113 & 323.045 .177 .741 & $1,00 \%$ & $(0,10 \%)$ \\
\hline 2017 & 3.688 .084 .550 & 332.495 .541 .853 & $1,10 \%$ & $0,10 \%$ \\
\hline 2018 & 4.439 .364 .139 & 359.592 .674 .230 & $1,23 \%$ & $0,13 \%$ \\
\hline Rata-rata & $\mathbf{3 . 2 9 1 . 3 0 0 . 7 4 1}$ & $\mathbf{3 1 1 . 7 8 0 . 4 9 1 . 6 8 0}$ & $\mathbf{1 , 0 5 \%}$ & $\mathbf{0 , 1 3 \%}$ \\
\hline
\end{tabular}

Sumber : Data Sekunder Yang Diolah Peneliti (2019)

Tabel 6 menjelaskan bahwa rata-rata kontribusi sektor pariwisata selama lima tahun sebesar 1,05\% terhadap PAD, dengan rincian pada tahun 2014 penerimaan pariwisata sebesar Rp 1.752.012.235 dan memberikan kontribusi terhadap PAD sebesar 0,68\%. Pada tahun 2015 penerimaan pariwisata meningkat menjadi Rp 3.194.311.672 dan memberikan kontribusi terhadap PAD sebesar 1,10\%, meningkat $0,42 \%$ dibandingkan pada tahun 2014. Pada tahun 2016 penerimaan pariwisata meningkat lagi 
menjadi Rp 3.382.731.113 dan memberikan kontribusi terhadap PAD sebesar 1,00\%, turun $0,10 \%$ dibandingkan tahun 2015. Kemudian pada tahun 2017 penerimaan pariwisata naik menjadi Rp 3.688.084.550 dan memberikan kontribusi terhadap PAD sebesar 1,10\%, meningkat $0,10 \%$ dibandingkan tahun 2016. Pada tahun 2018 penerimaan pariwisata naik menjadi Rp 4.439.364.139 dan memberikan kontribusi terhadap PAD sebesar 1,23\%, meningkat 0,13\% dibandingkan pada tahun 2017 .

Pertumbuhan pendapatan pariwisata menunjukkan kecenderungan meningkat terus dan puncaknya pada Tahun 2018 yang mencapai 1,23\%. Meningkatnya pendapatan pariwisata dapat dilihat dari perkembangan pendapatan sektor pariwisata di Kabupaten Nganjuk. Peranan masyarakat sendiri dalam industri pariwisata masih begitu kurang mungkin kurangnya penyuluhan dari pemerintah daerah tentang keuntungan dalam pengelolaan industri pariwisata itu sendiri serta masih minimnya keahlian masyarakat dalam pengelolaan industri pariwisata. Sehingga sektor pariwisata belum dapat memberikan kontribusi yang besar terhadap Pendapatan Asli Daerah di Kabupaten Nganjuk.

\section{KESIMPULAN DAN SARAN}

\section{Kesimpulan}

Dari hasil pembahasan pada bab IV dapat disimpulkan sebagai berikut:

1. Kontribusi retribusi obyek wisata di Kabupaten Nganjuk cenderung mengalami peningkatan dari tahun 2014 - 2018 akan tetapi kontribusi tersebut masih dibilang sangat kecil terhadap Pendapatan Asli Daerah sebesar 0,0060\% dan pertumbuhan sebesar $0,0007 \%$. Hal ini disebabkan karena jumlah obyek wisata di Kabupaten Nganjuk yang dikelola oleh pemerintah hanya 4 obyek wisata saja. Pada tahun 2015 penerimaan retribusi obyek wisata mengalami penurunan dikarenakan terjadi bencana alam di Air Terjun Sedudo yang mengakibatkan trauma bagi masyarakat untuk berwisata pada saat itu.

2. Jumlah obyek pariwisata mempunyai pengaruh yang signifikan terhadap pendapatan Dinas Pemuda, Olahraga, Kebudayaan dan Pariwisata Kabupaten Nganjuk. Hal ini disebabkan karena keinginan wisatawan akan sesuatu yang baru yang berkaitan dengan kegiatan pariwisata di Kabupaten Nganjuk sangat tinggi. 
3. Kontribusi Pajak hotel dan restoran juga mengalami peningkatan terus dari tahun 2014 - 2018, dengan rata-rata kontribusi pajak hotel dan restoran selama lima tahun tersebut sebesar 0,55\% terhadap Pendapatan Daerah dan pertumbuhannya $0,16 \%$ Peningkatan tertinggi terjadi pada tahun 2015, hal tersebut dikarenakan penambahan wajib pajak baru yaitu catering.

4. Kontribusi penerimaan retribusi wisatawan terhadap Pendapatan Asli Daerah mengalami penurunan dari tahun 2014 - 2017 dan mulai meningkat pada tahun 2018. Rata-rata kontribusi retribusi penerimaan wisatawan selama lima tahun sebesar 0,49\% terhadap Pendapatan Asli Daerah dan pertumbuhannya -0,042\%. Penurunan retribusi wisatawan ini disebabkan karena tidak ada pembaruan pada obyek wisata pada tahun 2017 ke bawah dan masih menggunakan PERDA Kabupaten Nganjuk Nomor 7 tahun 2011.

5. Kontribusi sektor pariwisata terhadap Pendapatan Asli Daerah pada tahun 2014 2018 mengalami peningkatan terus. Pada tahun 2018 penerimaan sektor pariwisata dari pajak Hotel dan restoran berada diposisi nomor empat dan dari retribusi pariwisata berada pada nomor lima di dalam penerimaan Pendapatan Asli Daerah. Hal ini menjelaskan bahwa sektor pariwisata merupakan sektor potensial bagi penerimaan daerah. Rata-rata kontribusi sektor pariwisata selama lima tahun sebesar 1,05\% terhadap Pendapatan Asli Daerah dan pertumbuhan sebesar 0,13\%.

\section{Saran}

1. Pemerintah Kabupaten Nganjuk harus terus berupaya meningkatkan strategi pemasaran pariwisata yang berdasarkan pada prioritas pengembangan obyek wisata, pangsa pasar, media yang tepat, pola kerja sama dan kemitraan serta promosi yang berkesinambungan. Promosi dapat dilakukan melalui berbagai kegiatan-kegiatan pariwisata yang berupa event-event seperti festival-festival, lomba-lomba, bazar, pentas seni (campur sari, wayang) yang dilakukan dalam rangka menarik minat wisatawan, baik wisatawan domestik maupun wisatawan asing yang bertujuan untuk meningkatkan pendapatan. Bahkan bisa melakukan kerja sama dengan pemerintah Kabupaten lain atau instansi terkait untuk memperluas promosi pariwisata. Selain itu karena industri pariwisata memerlukan dana investasi yang besar dengan jangka panjang maka pemerintah juga perlu untuk menarik para 
investor yang berminat menanamkan modalnya bagi perkembangan pariwisata di Kabupaten Nganjuk. Hal ini disebabkan karena investasi di sektor pariwisata sangat penting bagi pemerintah Kabupaten Nganjuk untuk menumbuhkan sektor-sektor ekonomi yang lain.

2. Koordinasi antar instansi atau dinas yang menangani masalah retribusi sektor pariwisata harus dilakukan secara terus menerus, sehingga jika terjadi permasalahan sekecil apapun yang menghambat efektivitas pelaksanaan perda retribusi sektor pariwisata dapat segera diatasi. Dengan begitu optimalisasi pendapatan Retribusi sektor pariwisata dalam meningkatkan Pendapatan Asli Daerah dapat terwujud.

3. Kedepannya Saran dari peneliti yaitu penambahan pengelolaan obyek wisata baru di Dinas Pariwisata, karena di Kabupaten Nganjuk perihal tentang kepariwisataan masih sangat potensial untuk dikembangkan lagi dan akan menjadi sumber penerimaan baru pada Pendapatan Asli Daerah.Selain itu pariwisata yang masih menjadi milik masyarakat dan perhutani dapat segera dipindahalihkan pengelolaan kepada Dinas Pariwisata, Kepemudaan, Olahraga dan Kebudayaan yang akan menambah Penerimaan Pendapatan Asli Daerah Kabupaten Nganjuk.

\section{DAFTAR PUSTAKA}

Adisasmita, Rahardjo. 2011. Pengelolaan pendapatan dan anggaran daerah. Yogyakarta: Graha Ilmu.

Anggoro, Damas Dwi. 2017. Pajak Daerah dan Retribusi Daerah. Malang: Universitas Brawijaya Press.

Baini, Nirmala. 2018. Analisis Pengaruh Sektor Pariwisata terhadap Pendapatan Asli Daerah di Nusa Tenggara Barat tahun 2009-2015. Skripsi. Yogyakarta. Universitas Islam Negeri Sunan Kalijaga.

Dewandaru, B., \& Purnamaningsih, N. (2016). Strategi Dalam Memajukan Industri Kreatif Sebagai Daya Tarik Wisata. Jurnal Ekonomi Universitas Kediri, 1(2), 170 187.

Putra, Y. P., \& Heryanto, B. (2017). Pemetaan Kepemilikan Badan Hukum dan Tingkat Penggunaan Teknologi Informasi pada UMKM (Studi pada Kelurahan Pojok Kecamatan Mojoroto-Kota Kediri). Ekonika: Jurnal Ekonomi Universitas Kadiri, 2(2), 183-197.

Dinas Pariwisata dan Kebudayaan Kabupaten Nganjuk. 2019. Data Penerimaan Realisasi Retribusi Pariwisata Kabupaten Nganjuk tahun 2014-2018. Nganjuk.

Dinas Pendapatan Kabupaten Nganjuk. 2019. Data pendapatan pajak hotel dan Restoran, serta Pendapatan Asli Daerah 2014- 2018.Nganjuk.

Fitri, Devilian. 2014. Pengaruh Sektor Pariwisata Terhadap Pendapatan Asli Daerah di Kabupaten Pesisir Selatan. Jurnal. Padang. STKIP PGRI Sumatra Barat. 
Handayani, Dhina. 2012. Analisis Kontribusi Sektor Pariwisata terhadap Pendapatan Asli Daerah di Kabupaten Ngawi tahun 2003-2010. Tesis. Surakarta. Universitas Sebelas Maret.

Isnaini, Arif Wahyu. 2014. Studi Potensi Ekonomi Sektor Pariwisata terhadap Pendapatan Asli Daerah Kabupaten Tulungagung. Jurnal Universitas Brawijaya.

Indriantoro, Nurdan Bambang Supomo. (2011). Metodologi Penelitian Bisnis untuk Akuntansi dan Manajemen. Edisi pertama. Yogyakarta: BPFE.

Badan Pusat Statistika Kabupaten Nganjuk. 2019. Kabupaten Nganjuk Dalam Angka 2018. Nganjuk.

Muljadi, A.J. (2010). Kepariwisataan dan Perjalanan. Jakarta: PT Raja Grafindo Persada.

Pertiwi. (2014). Pengaruh Kunjungan Wisatawan, Retribusi Obyek Wisata dan PHR terhadap PAD Kabupaten Gianyar. E-Jurnal EP Unud, Vol.3, No. 3.

Peraturan Daerah Kabupaten Nganjuk Nomor 6 Tahun 2018 tentang Retribusi Jasa Usaha

Paradilla, Shintya. 2016. Kontribusi Sektor Pariwisata terhadap Pendapatan Asli Daerah Kota Sawahlunto 2010-2015. Jurnal. Sumatra Barat. STKIP PGRI

Dewandaru, B., \& Purnamaningsih, N. (2016). Strategi Dalam Memajukan Industri Kreatif Sebagai Daya Tarik Wisata. Jurnal Ekonomi Universitas Kediri, 1(2), 170187.

Putra, Y. P., \& Heryanto, B. (2017). Pemetaan Kepemilikan Badan Hukum dan Tingkat Penggunaan Teknologi Informasi pada UMKM (Studi pada Kelurahan Pojok Kecamatan Mojoroto-Kota Kediri). Ekonika: Jurnal Ekonomi Universitas Kadiri, 2(2), 183-197.

Rosa, Yenni Del. 2016. Analisis Dampak Sektor Pariwisata terhadap Pendapatan Asli Daerah Kabupaten Pesisir Selatan Tahun 2000-2014. Jurnal Ekonomi dan Bisnis Universitas Dharma Andalas, Vol. 18, No. 1.

Saputra, Rian. 2018. Pengaruh Jumlah Wisatawan, Jumlah Objek Wisata, dan Retribusi Objek Wisata terhadap Pendapatan Asli Daerah Kabupaten Gunung Kidul 20122016. Skripsi. Yogyakarta. STIE Widya Wiwaha.

Sanusi, Anwar. (2011). Metode Penelitian Bisnis.

Siahaan, Maribot. (2009). Pajak Daerah dan Retribusi Daerah. Edisi Revisi. Jakarta: PT. Raja Grafindo Prsada.

Sugiyono.(2011). Statistika untuk Penelitian. Bandung: Alfabeta.

Widiastuti, Ni Komang. 2010. Pengaruh Sektor Pariwisata terhadap Kinerja Keuangan Daerah dan Kesejahteraan Masyarakat Kabupaten/Kota di Provinsi Bali. Skripsi. Bali. Universitas Udayana.

Wulandari, P. A., Emy, I.(2018). Pajak Daerah dalam Pendapatan Asli Daerah. Banjarmasin: CV Budi Utama. 